J. Ris. \& Ap. Mat. Vol. 3 No.2 (2019) pp. 89-100

Jurnal Riset dan Aplikasi Matematika

e-ISSN: 2581-0154

URL: journal.unesa.ac.id/index.php/jram

\title{
PENGARUH OUTPUT SEKTOR PERTANIAN DAN PERDAGANGAN TERHADAP KEMISKINAN DI PROVINSI KALIMANTAN TENGAH
}

\author{
Pendekatan Model Regresi Data Panel Periode 2010-2017
}

\author{
ANANTO WIBOWO \\ Badan Pusat Statistik Kotawaringin Barat
}

*ananto.wibowo@bps.go.id

\begin{abstract}
ABSTRAK
Pengentasan tingkat kemiskinan di Provinsi Kalimantan Tengah (Kalteng) semakin melambat. Ada kemungkinan, orang-orang yang berhasil keluar dari kemiskinan adalah mereka yang pengeluarannya cukup dekat dengan garis kemiskinan. Beberapa hasil studi telah menunjukkan bahwa kemiskinan berkaitan erat dengan eksistensi sektor perdagangan dan pertanian. Penelitian ini bertujuan untuk menganalisis pengaruh output sektor pertanian dan perdagangan terhadap tingkat kemiskinan di Provinsi Kalteng dengan menggunakan regresi data panel agar mampu menangkap heterogenitas pada masingmasing kabupaten/kota. Sumber data berasal dari Badan Pusat Statistik (BPS) Provinsi Kalimantan Tengah periode 2010-2017. Hasil analisis menunjukkan bahwa model regresi data panel pendekatan fixed effects dan estimasi parameter Seemingly Unrelated Regression (SUR) merupakan regresi yang paling tepat dengan Adjusted R-Square yang dihasilkan sebesar 0,8592. Berdasarkan kajian empiris, kenaikan output sektor pertanian sebesar satu triliun rupiah mampu menurunkan persentase kemiskinan kabupaten/kota di Kalteng sebesar 1,76 persen, sedangkan pada sektor perdagangan kenaikan output sebesar satu triliun rupiah mengakibatkan persentase kemiskinan turun sebesar 1,01 persen.
\end{abstract}

Kata Kunci: Kemiskinan, Pertanian, Perdagangan, Regresi Data Panel

\begin{abstract}
Poverty alleviation is slowing down in Central Kalimantan Province. It is possible that the people who made it out of poverty are those whose expenses are quite close to the poverty line. Several studies have shown that poverty is closely related to the existence of the trade and agricultural sector. This research aims to analyze the effect of agricultural and trade sector output on the poverty level in Central Kalimantan Province using panel data regression to capture the heterogeneity in each regency and municipality. The data used in this research were sourced from Statistics of Central Kalimantan Province (BPS) with the period 2010-2017. The results of the analysis show that data panel regression with fixed effects approach and parameter estimation Seemingly Uncorrelated Regression (SUR) is the most appropriate regression with Adjusted $R$-Square 0.8592. Based on empirical studies, an increase of agricultural sector output of one trillion Rupiah could reduce the percentage of poverty in Regencies and/or Municipalities in Central Kalimantan Province by 1.76 percent. Whereas in the trade sector, an increase of output in one trillion Rupiah could cause poverty percentage reduction by 1.01 percent.
\end{abstract}

Keywords: Poverty, Agricultural, Trade, Panel Data Regression

2010 Mathematics Subject Classification: 62J05

Tanggal Masuk: 17-08-19; direvisi: 29-10-19; diterima: 31-10-19 


\section{Pendahuluan}

Terdapat beberapa isu utama yang dibahas dalam Sustainable Development Goals (SDGs) diantaranya pengentasan segala bentuk kemiskinan dan mengakhiri kelaparan dengan pencapaian ketahanan pangan. Berdasarkan publikasi Badan Pusat Statisik (BPS), persentase kemiskinan di Provinsi Kalimantan Tengah (Kalteng) terus menunjukkan penurunan yang cukup baik semenjak krisis 1998 hingga mencapai 5,17 persen pada tahun 2017 [10]. Namun, tetap perlu usaha keras untuk mewujudkan target SDGs tanpa kemiskinan pada tahun 2030. Pasalnya penurunan kemiskinan semakin lambat, hanya sekitar dua persen dalam kurun sepuluh tahun terakhir [3]. Ada kemungkinan, orang-orang yang berhasil keluar dari kemiskinan adalah orang-orang yang pengeluarannya cukup dekat dengan garis kemiskinan [3]. Sementara orangorang yang hidupnya jauh sekali dari garis kemiskinan tidak tersentuh oleh program-program pengentasan kemiskinan [3].

Beberapa studi juga menunjukkan bahwa tingkat kemiskinan berkaitan erat dengan sektor pertanian. Seperti yang dilakukan oleh Herawan [8] dimana sektor pertanian berperan penting terhadap pengurangan kemiskinan di perdesaan dibandingkan dengan daerah perkotaan dengan lokus kajian di Indonesia. Penelitian tersebut juga didukung dengan publikasi BPS pada tahun 2018 [1] dimana lebih dari separuh penduduk miskin kabupaten/kota Kalteng dominan bekerja pada sektor pertanian (sekitar 50,45 persen). Di sisi lain, share Produk Domestik Regional Bruto (PDRB) sektor pertanian juga yang tertinggi atau 21 persen dari kue ekonomi secara keseluruhan [9]. Ini berarti sektor pertanian memegang peranan penting dalam perkonomian di Provinsi Kalteng.

Pada sektor perdagangan, share PDRB kalteng terus mengalami peningkatan dari 10,97 persen pada tahun 2010 menjadi 12,02 persen di tahun 2017 [9]. Hasil sensus ekonomi 2016 juga menunjukkan bahwa jumlah usaha sektor perdagangan di Kalteng mencapai 48,40 persen dari keseluruhan usaha non pertanian. Dilihat dari daya serap terhadap tenaga kerja, sektor perdagangan mampu menggerakkan sekitar 31,25 persen dari seluruh tenaga kerja non pertanian. Dengan kata lain, satu diantara tiga tenaga kerja pada usaha nonpertanian, bekerja pada kategori sektor perdagangan [2]. Studi yang dilakukan Mitra [13] juga menyimpulkan bahwa perdagangan memengaruhi kemiskinan dengan beberapa bukti empiris seperti tingkat kemiskinan yang turun dramatis di China dan India akibat kenaikan sektor perdagangan. Efek perdagangan terhadap kemiskinan sangat besar pengaruhnya pada negara-negara berkembang [13]. Sektor perdagangan dianggap mampu meningkatkan pendapatan dan pertumbuhan ekonomi serta menurunkan tingkat kemiskinan [13].

Berdasarkan uraian di atas, penelitian ini bertujuan untuk menganalisis pengaruh sektor pertanian dan perdagangan terhadap kemiskinan di Provinsi Kalteng melalui model statistik. Metode yang digunakan adalah pemodelan regresi data panel. Melalui data panel, peneliti mampu menyelidiki berbagai proses ekonomi sambil menghitung heterogenitas antar kabupaten dan efek dinamis yang tidak dapat terlihat dalam data cross section [6].

\section{Tinjauan Pustaka}

Terdapat beberapa macam pendekatan model data panel menurut Baltagi [4] diantaranya pendekatan kuadrat terkecil (common effects), pendekatan efek tetap (fixed effects) dan pendekatan efek acak (random effects). Pendekatan common effects tidak mengasumsikan adanya efek waktu dan efek individu atau biasa disebut model regresi linier [17]. Model ini dapat ditulis:

$y_{i t}=a+\beta X_{i t}+\mu_{i t}$ untuk $i=1,2,3, \ldots, N$ dan $t=1,2,3, \ldots T$

dimana 


$$
\beta^{\prime}=\left[\begin{array}{llll}
\beta_{1} & \beta_{2} & \ldots & \beta_{k}
\end{array}\right] \operatorname{dan} X_{i t}=\left[\begin{array}{c}
X_{1 i t} \\
X_{2 i t} \\
\vdots \\
X_{k i t}
\end{array}\right]
$$

dengan $i$ menunjukkan cross section (individu), $t$ merupakan periode waktu, dan $k$ adalah jumlah variabel bebas.

Adapun pendekatan model fixed effects mengasumsikan terdapatnya efek individu dan diakomodasi melalui perbedaan intersep $a_{i}$ dengan model:

$$
y_{i t}=a_{0}+a_{i}+\beta X_{i t}+\mu_{i t} \text { untuk } i=1,2,3, \ldots, N \text { dan } t=1,2,3, \ldots T
$$

dimana $\mu_{i t}$ merupakan error untuk unit observasi ke- $i$ dan waktu ke- $t$ dengan $E\left(\mu_{i t}\right)=0$.

Asumsi pada model Fixed Effects adalah:

$$
E\left(\mu_{i t} \mid X_{i}, a_{i}\right)=0
$$

dan penerapan metode estimasi least squares [11] untuk mendapatkan parameter $\beta$ didapatkan dengan formula berikut:

$$
\hat{\beta}_{L I N-F E}=\underset{\beta}{\operatorname{argmin}} \sum_{i=1}^{N} \sum_{t=1}^{T}\left\{\left(Y_{i t}-\bar{Y}_{i}\right)-\beta\left(X_{i t}-\bar{X}_{i}\right\}^{2}\right.
$$

dimana $\bar{Y}_{i}=\sum_{t=1}^{T} Y_{i t} / T$ dan $\bar{X}_{i}=\sum_{t=1}^{T} X_{i t} / T$ adapun $\hat{\beta}_{L I N-F E}$ merupakan unbiased estimator dari $\beta$.

Berbeda dengan model common dan fixed effects, model random effects mengasumsikan efek spesifik individu didistribusikan melalui bagian dari komponen error yang bersifat acak dan tidak berkorelasi dengan variabel penjelas [17] . Model ini dapat ditulis sebagai berikut:

$y_{i t}=a+\beta X_{i t}+w_{i t}$ untuk $i=1,2,3, \ldots, N$ dan $t=1,2,3, \ldots T$

dimana $w_{i t}=\varepsilon_{i}+\mu_{i t}$

dengan $\varepsilon_{i}$ adalah komponen error spesifik individu atau cross section sedangkan $\mu_{i t}$ adalah komponen error kombinasi time series dan cross section dan estimasi parameter yang digunakan pada model random effects adalah Generalized Least Square (GLS). Estimasi dari GLS menurut Mućk [14] adalah sebagai berikut:

$$
\begin{aligned}
& \hat{\beta}^{G L S}=\left(X^{\prime} \Sigma^{-1} X\right)^{-1} X^{\prime} \Sigma^{-1} y \\
& \operatorname{dimana} \Sigma=E\left(u u^{\prime}\right)=\left({\sigma_{\mu}}^{2}+{\sigma_{\varepsilon}}^{2}\right)\left[\begin{array}{cccc}
1 & \rho & \cdots & \rho \\
\rho & 1 & \ldots & \rho \\
\vdots & \vdots & \ddots & \vdots \\
\rho & \rho & \ldots & 1
\end{array}\right] \text { dan } \rho=\frac{\sigma_{\mu}{ }^{2}}{\left(\sigma_{\mu}{ }^{2}+\sigma_{\varepsilon}{ }^{2}\right)} .
\end{aligned}
$$

Nilai $\sigma_{\mu}{ }^{2}=\frac{\sum_{i=1}^{N} \bar{y}_{i}-\beta_{0}-\bar{x}_{i} \beta}{N-K}-\frac{\hat{\sigma}_{\varepsilon}{ }^{2}}{\bar{T}}$, sedangkan $\hat{\sigma}_{\varepsilon}{ }^{2}=\frac{\sum_{i=1}^{N} \sum_{t=1}^{T_{i}} \widehat{\mu}_{i t}{ }^{2}}{N T-N-K+1}$ dengan $\bar{T}=\frac{n}{\sum_{i=1}^{n}\left(\frac{1}{T_{i}}\right)}$. Beberapa asumsi yang harus dipenuhi pada model random effects menurut Wooldridge [18] adalah:

a. $\varepsilon_{i} \sim N\left(0, \sigma_{\varepsilon}^{2}\right)$

b. $\mu_{i t} \sim N\left(0, \sigma_{\mu}^{2}\right)$

c. $E\left(\varepsilon_{i} \mu_{i t}\right)=0$

d. $E\left(\varepsilon_{i} \varepsilon_{j}\right)=0, i \neq j$

e. $E\left(\mu_{i t} \mu_{i s}\right)=E\left(\mu_{i t} \mu_{j t}\right)=E\left(\mu_{i t} \mu_{j s}\right)=0, i \neq j ; t \neq s$

\subsection{Pemilihan Model Regresi Data Panel}

Pemilihan model terbaik pada regresi data panel juga lebih banyak dilakukan dengan ujiuji statistik diantaranya uji Chow dan uji Hausman. Uji chow digunakan dengan membandingkan model fixed effects dengan model common effects. Formula statistik uji Hausman menurut Baltagi [4] adalah: 


$$
F=\frac{\left(R S S_{1}-R S S_{2}\right) / n-1}{R S S_{2} /(n T-n-k)} \sim F_{(\alpha ; n-1 ; n T-n-k)}
$$

dimana $n=$ jumlah individu; $T=$ periode observasi; $k=$ jumlah parameter dalam model fixed effects; $R S S_{1}$ adalah residual sum of squares model common effects, sedangkan $R S S_{2}$ residual sum of squares model fixed effects. Jika nilai statistik F hitung lebih besar daripada $\mathrm{F}$ tabel, maka hipotesis nol akan ditolak sehingga dapat disimpulkan bahwa model fixed effects lebih baik digunakan daripada model common effects.

Uji statistik lainnya yakni uji Hausman bertujuan untuk memilih model terbaik antara model fixed effects dengan model random effects dengan formula [18]:

$$
W=\left(\hat{\beta}_{F E M}-\hat{\beta}_{R E M}\right)^{\prime}\left[\operatorname{var}\left(\hat{\beta}_{F E M}-\hat{\beta}_{R E M}\right)\right]^{-1}\left(\hat{\beta}_{F E M}-\hat{\beta}_{R E M}\right) \sim \chi^{2}{ }_{(k)}
$$

dimana $\hat{\beta}_{F E M}$ adalah vektor estimasi slope pada model fixed effects dan $\hat{\beta}_{R E M}$ adalah vektor estimasi slope pada model random effects. Hipotesis nol dari uji Hausman adalah model Random Effects lebih baik dibanding model Fixed Effects. Apabila output yang diperoleh dengan nilai $p$-value yang lebih kecil dari tingkat signifikansi lima persen, maka hipotesis null akan ditolak dan disimpulkan bahwa model fixed effects lebih baik dibanding model random effects. Sebaliknya, apabila output yang diperoleh dengan nilai $p$-value yang lebih besar dari taraf signifikansi lima persen maka dapat disimpulkan bahwa model random effects lebih baik dari fixed effects.

Selanjutnya, jika hasil Uji Hausman menyatakan bahwa fixed effects terpilih sebagai model yang lebih baik, maka diperlukan pemeriksaan terhadap matriks struktur varianskovarians residual yang dihasilkan. Kemungkinan yang terjadi diantaranya terdapat masalah heteroskedastik dimana suatu kondisi varians residual yang tidak konstan dan autokorelasi atau kondisi terjadinya hubungan yang kuat antar residual [18]. Oleh karena itu, beberapa hal yang perlu dilakukan pada model fixed effects adalah sebagai berikut [16]:

1. Struktur bersifat homoskedastik dan tidak terdapat autokorelasi. Apabila sifat struktur matriks varians-kovarians residual adalah homoskedastik dan tidak terdapat autokorelasi, maka metode estimasi yang tepat digunakan adalah Ordinary Least Squares.

2. Struktur bersifat heteroskedastik dan tidak terdapat autokorelasi. Apabila sifat struktur matriks varians-kovarians residual adalah heteroskedastik dan tidak terdapat autokorelasi, maka metode estimasi yang tepat digunakan adalah Generalized Least Squares.

3. Struktur bersifat heteroskedastik dan terdapat autokorelasi Apabila sifat struktur matriks varians-kovarians residual adalah heteroskedastik dan terdapat autokorelasi, maka metode estimasi yang tepat digunakan adalah Feasible Generalized Least Squares (FGLS) atau Seemingly Unrelated Regression (SUR).

Pengujian struktur matriks untuk mendeteksi heteroskedastis dilakukan dengan Uji Lagrange Multiplier [16] sedangkan nonautokorelasi diuji dengan menggunakan nilai statistik uji Durbin-Watson. Nilai Durbin-Watson yang terbentuk berada pada rentang nol hingga empat. Apabila nilai D yang diperoleh sangat jauh dari angka dua, maka terindikasi adanya nonautokorelasi. Selain itu, model akhir regresi data panel yang terbentuk juga harus memenuhi uji asumsi normalitas dan non multikolinieritas.

\subsection{Pengujian Keberartian Model}

Penilaian kelayakan suatu model regresi data panel diukur dengan menggunakan koefisien determinasi yang menjelaskan keragaman variabel dengan formula sebagai berikut:

$$
R^{2}{ }_{a d j}=1-\left(\left(1-\frac{\sum\left(\hat{Y}_{i}-\bar{Y}\right)^{2}}{\sum\left(Y_{i}-\bar{Y}\right)^{2}}\right)\left(\frac{n T-1)}{n T-n-k}\right)\right)
$$


Selanjutnya, dilakukan pengujian apakah terdapat minimal salah satu variabel penjelas yang berpengaruh terhadap variabel respon dilakukan dengan uji-F dimana:

$$
\mathrm{F}=\frac{\sum\left(\hat{Y}_{i}-\bar{Y}\right)^{2} /(n+k-1)}{\sum\left(Y_{i}-\hat{Y}_{i}\right)^{2} /(n T-n-k)}
$$

dengan:

$H_{0}: \quad \beta_{1}=\beta_{2}=\ldots=\beta_{\mathrm{p}}=0$ (tidak terdapat pengaruh variabel penjelas secara simultan terhadap variabel respon)

$H_{1}$ : minimal terdapat satu $\beta_{\mathrm{j}} \neq 0 ; j=1,2, \ldots, p$ (minimal terdapat satu variabel penjelas yang berpengaruh terhadap variabel respon)

Wilayah kritis untuk menolak $H_{0}$ dengan taraf nyata 5\% adalah: $F>F_{0,05(n+k-1 ; n T-n-k)}$. Apabila $H_{0}$ ditolak, maka dilakukan uji parsial dengan statistik uji yang digunakan adalah:

$$
t_{\text {hit }}=\frac{\widehat{\beta}_{\mathrm{j}}}{\operatorname{SE}\left(\widehat{\beta}_{\mathrm{j}}\right)}
$$

dengan:

$H_{0}: \quad \beta_{\mathrm{j}}=0$ (tidak terdapat pengaruh variabel penjelas ke-j terhadap variabel respon)

$H_{1}: \quad \beta_{\mathrm{j}} \neq 0$ (terdapat pengaruh variabel penjelas ke-j terhadap variabel respon)

Adapun wilayah kritis untuk menolak $H_{0}$ dengan taraf nyata 5\% adalah: $t>t_{0,05(n T-k-1)}$.

\subsection{Sumber Data dan Variabel Penelitian}

Pengumpulan data yang digunakan dalam penelitian ini memanfaatkan data sekunder bersumber dari Badan Pusat Statistik (BPS) seluruh Kabupaten/Kota di Provinsi Kalteng periode 2010 hingga 2017. Variabel yang digunakan diantaranya persentase kemiskinan sebagai variabel tak bebas serta output PDRB sektor perdagangan, dan pertanian atas dasar harga konstan masing-masing kabupaten kota sebagai variabel bebas. Pertimbangan atas dasar harga konstan karena tidak ada pengaruh inflasi tahunan yang terjadi pada periode penelitian. Adapun pembentukan model regresi data panel serta seluruh uji asumsi klasik didukung dengan perangkat lunak Eviews 7.0, SPSS 20 dan Sistem Informasi Geografis untuk pembuatan peta spasial.

\section{Hasil dan Pembahasan}

\subsection{Gambaran Umum Kemiskinan Kabupaten/Kota}

Level kemiskinan pada tingkat kabupaten/kota di Kalteng secara perlahan terus menurun dari tahun 2010 hingga tahun 2016. Capaian persentase kemiskinan terendah terjadi di Kabupaten Sukamara sebesar 3,36 persen pada tahun 2017, sedangkan persentase tertinggi berada di Kabupaten Seruyan sebesar 8,08 persen [10]. Hal ini senada dengan penetapan Kabupaten Seruyan sebagai satu-satunya daerah tertinggal di Provinsi Kalteng.

Pada sisi spasial, persentase kemiskinan Kalteng memiliki variasi yang cukup kecil antar kabupaten/kota. Hal tersebut terlihat dari angka persentase setiap daerah yang masih berada pada rentang 1 digit. Hanya Kabupaten Barito Timur yang lebih dua digit pada tahun 2010 dan terus menurun cukup cepat hingga 7,17 persen pada tahun 2017. Selain itu, Barito Selatan merupakan kabupaten tercepat dalam menurunkan angka kemiskinan hingga lebih dari 3 persen dalam kurun waktu enam tahun, sedangkan kabupaten yang dinilai paling lambat dalam menurunkan persentase kemiskinan adalah Pulang Pisau.

Berdasarkan informasi pada Gambar 1, secara umum tingkat kemiskinan kabupaten/ kota di Kalteng dominan pada rona warna kuning dengan rentang 6 hingga 7 persen. Hal ini 
cukup baik dalam pembangunan dan hanya terjadi pada enam kabupaten diantaranya Kotawaringin Timur, Katingan, Gunung Mas, Kapuas, Barito Selatan dan Murung Raya. Selanjutnya, Kabupaten Lamandau, Sukamara dan Kota Palangka Raya bisa menjadi acuan dalam pembelajaran pembangunan bagi wilayah lainnya karena memiliki rata-rata persentase kemiskinan terendah dengan rentang 4 hingga 5 persen. Namun demikian, fokus utama pembangunan Provinsi Kalteng diharapkan bisa berpusat pada Kabupaten Seruyan dan Barito Timur karena secara rata-rata kedua kabupaten tersebut memiliki rentang terburuk atau lebih dari 8 persen apabila dibandingkan wilayah yang lain.

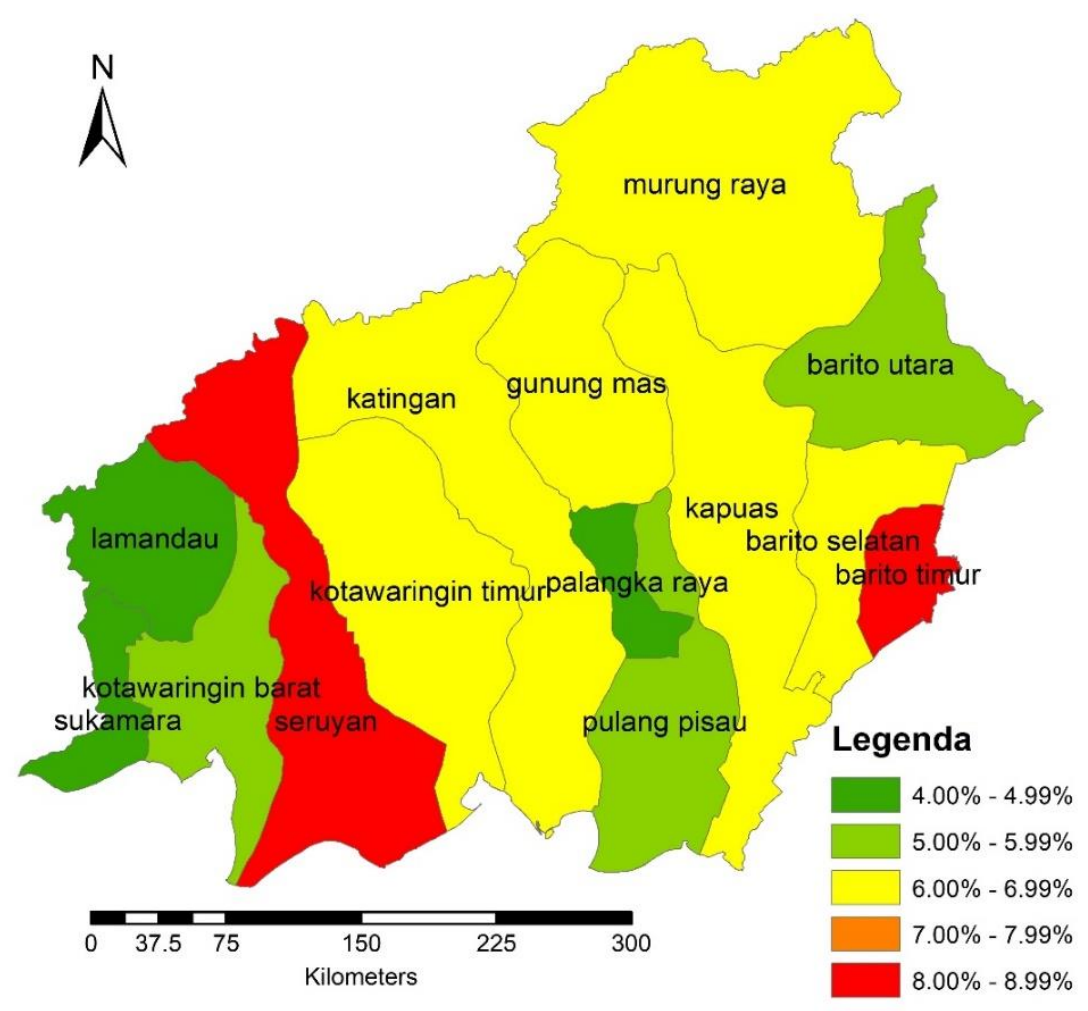

Gambar 1. Rata-Rata Persentase Kemiskinan Kabupaten/Kota Provinsi Kalteng Periode 2010-2017

\subsection{Pemilihan Model}

Berdasarkan hasil Uji-Chow pada Tabel 1 didapat nilai $F$-Statistic yang lebih besar dari nilai $F$-table atau nilai $p$-value sebesar 0,000 yang lebih kecil dari 0,05 . Sehingga dapat disimpulkan bahwa hipotesis null ditolak atau model regresi fixed effects lebih baik digunakan daripada common effects dalam pemodelan regresi data panel.

Tabel 1. Uji Chow

\begin{tabular}{|c|c|c|c|}
\hline Uji & Statistik & Derajat Bebas & P-value \\
\hline Cross-Section F & 28,89 & $13 / 96$ & 0.000 \\
\hline Cross-Section Chi-square & 178,29 & 13 & 0.000 \\
\hline
\end{tabular}

Kemudian dilakukan perbandingan antara model antara fixed effects dengan random effects menggunakan Uji Hausman. Hasil perhitungan ini ditunjukkan oleh Tabel 2 dengan hipotesis null dimana random effects lebih baik dari fixed effects ditolak. Hal ini terjadi karena 
p-value lebih kecil dari taraf signifikansi sebesar 5 persen atau model fixed effects lebih baik dari random effects. Dengan demikian, berdasarkan hasil pengujian ketiga model data panel, model fixed effects merupakan yang paling tepat untuk mengetahui pengaruh output sektor pertanian dan perdagangan terhadap persentase kemiskinan periode 2010-2017.

Ketika fixed effects terpilih sebagai model terbaik, dilakukan pengujian terhadap matriks varians-kovarians residualnya. Hal ini sangatlah penting untuk mengetahui estimator apakah yang paling tepat digunakan terhadap nilai vektor slope pada model yang akan terbentuk. Hasil uji yang diperoleh dengan Lagrange-Multiplier menunjukkan bahwa nilai statistik $\chi^{2}=$ 405,76 lebih besar dari nilai kritis sebesar 98,39. Oleh karena itu dapat diputuskan bahwa hipotesis null ditolak atau struktur matriks varians-kovarians residualnya bersifat heterosekdastik.

Tabel 2. Uji Hausman

\begin{tabular}{|c|c|c|c|}
\hline Uji & Statistik & Derajat Bebas & P-value \\
\hline Cross-Section random & 28,21 & 2 & 0.000 \\
\hline
\end{tabular}

Pada tahapan selanjutnya dilakukan pemeriksaan terhadap residual pada sisi autokorelasi. Hasil pengujian menunjukkan autokorelasi yang terjadi sangat positif. Nilai Durbin-Watson yang diperoleh sebesar 0,61 dan sangat jauh dari angka dua bahkan mendekati nilai nol. Oleh karena itu, pendekatan regresi data panel yang digunakan adalah fixed effects dengan struktur varians-kovarians residual bersifat heteroskedastik dan ada autokorelasi. Dengan kata lain, estimasi parameter yang paling tepat adalah Seemingly Uncorrelated Regession (SUR).

Tabel 3. Uji Kenormalan Residual

\begin{tabular}{|l|c|l|c|}
\hline \multicolumn{1}{|c|}{ Kabupaten/Kota } & $\boldsymbol{P}$-Value & Kabupaten/Kota & P-Value \\
\hline Kotawaringin Barat & 0,73 & Seruyan & 0,98 \\
\hline Kotawaringin Timur & 0,65 & Katingan & 0,90 \\
\hline Kapuas & 0,87 & Pulang Pisau & 0,74 \\
\hline Barito Selatan & 0,76 & Gunung Mas & 0,45 \\
\hline Barito Utara & 0,46 & Barito Timur & 0,72 \\
\hline Sukamara & 0,71 & Murung Raya & 0,94 \\
\hline Lamandau & 0,75 & Palangka Raya & 0,26 \\
\hline
\end{tabular}

Hasil pemodelan data panel dengan pendekatan fixed effects dan estimasi parameter SUR yang terbentuk juga harus memenuhi asumsi normalitas dan non multikolinieritas. Kedua uji asumsi ini perlu dilakukan agar model akhir yang telah terpilih tidak menyesatkan peneliti saat membaca seluruh output. Berdasarkan uji statistik menggunakan Jarque-Bera test untuk masing-masing kabupaten/kota diperoleh bahwa nilai $p$-value seluruh kabupaten/kota jauh melebihi 0,05 menandakan bahwa hypotesis null tidak ditolak atau hasil pemodelan data panel telah memenuhi uji asumsi normalitas (Tabel 3). 
Pada uji multikolinieritas dilakukan pemeriksaan apakah terdapat hubungan yang kuat antar variabel independen dalam model. Apabila multikoliniertas terjadi maka estimasi slope menjadi tidak presisi dan uji parsial tidaklah valid ketika digunakan [16]. Pada uji asumsi non multikolinieritas yang ditunjukkan pada tabel 4, diperoleh nilai VIF pada setiap variabel kurang dari lima. Dengan kata lain, asumsi non multikolinieritas telah terpenuhi atau tidak ada korelasi yang kuat antarvariabel independen.

Tabel 4. Uji Non Multikolinieritas

\begin{tabular}{|c|c|}
\hline Variabel & VIF \\
\hline Pertanian & 1,76 \\
\hline Perdagangan & 1,76 \\
\hline
\end{tabular}

\subsection{Hasil Pengujian Keberartian Model dan Interpretasi}

Setelah dilakukan pemilihan model terbaik dan uji asumsi klasik, maka didapatkan persamaan data panel yang akan digunakan dalam penelitian. Hasil output disalin dari program eviews (Tabel 5) dimana pendekatan fixed effects dan estimasi parameter menggunakan SUR dapat ditulis sebagai berikut:

dengan:

$$
T K_{i t}=8,83+a_{i}-1,79 \times 10^{-6} A_{i t}-1,01 \times 10^{-6} G_{i t}+\mu_{i t}
$$

$T K_{i t}=$ Persentase kemiskinan pada kabupaten/kota ke $i$ dan waktu ke $t$

$A_{i t} \quad=$ Output PDRB pertanian pada kabupaten/kota ke $i$ dan waktu ke $t$

$G_{i t}=$ Output PDRB perdagangan pada kabupaten/kota ke $i$ dan waktu ke $t$

Model ini didapatkan dari perhitungan [14]:

$\hat{\beta}^{\text {SUR }}=\left(X^{\prime} \hat{\Omega}^{-1} X\right)^{-1} X^{\prime} \hat{\Omega}^{-1} y$ dengan $\hat{\Omega}=\left[\begin{array}{cccc}\hat{\sigma}_{11}{ }^{2} I & \hat{\sigma}_{12}{ }^{2} I & \cdots & \hat{\sigma}_{1 k}{ }^{2} I \\ \hat{\sigma}_{21}{ }^{2} I & \hat{\sigma}_{22}{ }^{2} I & \ldots & \hat{\sigma}_{2 k}{ }^{2} I \\ \vdots & \vdots & \ddots & \vdots \\ \hat{\sigma}_{k 1}{ }^{2} I & \hat{\sigma}_{k 2}{ }^{2} I & \ldots & \hat{\sigma}_{k k}{ }^{2} I\end{array}\right]$

Tabel 5. Model Regresi Data Panel Pendekatan Fixed Effects dengan Estimasi SUR

\begin{tabular}{|c|c|c|c|}
\hline Variabel & Koefisien & Standard Error & P-value \\
\hline C & 8,83 & 0,30 & 0,00 \\
\hline Pertanian & $-1,76 \times 10^{-6}$ & $3,99 \times 10^{-7}$ & 0,00 \\
\hline Perdagangan & $-1,01 \times 10^{-6}$ & $4,71 \times 10^{-7}$ & 0,03 \\
\hline \multicolumn{3}{|c|}{ Weighted Statistics } \\
\hline & R-Squared 0,8783 \\
\hline & Adjusted R-Squared 0,8592 \\
\hline
\end{tabular}

Adapun nilai $a_{i}$ merupakan efek tetap (fixed) yang ditunjukkan oleh Tabel 6 dan berbeda-beda setiap kabupaten/kota. Hasil Adjusted $R$-Square sebesar 0,8592 dibaca sebagai variasi output sektor perdagangan dan pertanian yang mampu menjelaskan variasi persentase 
kemiskinan sebesar 85,92 persen dengan mempertimbangkan penambahan variabel lain di dalam model, sedangkan 14,08 persen lainnya mampu dijelaskan oleh variabel-variabel yang tidak termasuk dalam model. Nilai ini sangat baik dalam pemodelan data panel karena berada pada rentang Adjusted $R$-Square lebih dari 80 persen.

Sebelum interpretasi dilakukan, uji keberartian baik secara simultan maupun parsial merupakan tahap awal dalam membaca output regresi. Berdasarkan hasil yang diperoleh, uji simultan $F$ menunjukkan bahwa minimal terdapat salah satu variabel prediktor yang berpengaruh terhadap variabel respon. Hal ini dapat dibuktikan oleh $F_{\text {hitung }}$ sebesar 46,18 atau p-value dengan nilai 0,00 yang berarti $H_{0}$ ditolak.

Selain itu, hasil uji parsial dengan menggunakan nilai t-hitung diperoleh bahwa seluruh variabel telah signifikan memengaruhi variabel tak bebas diantaranya output sektor perdagangan dan pertanian. Secara keseluruhan nilai $p$-value masing-masing variabel mendekati nilai nol dan kurang dari nilai 0,05 . Dengan kata lain, $H_{0}$ ditolak atau output sektor perdagangan dan pertanian memiliki pengaruh terhadap persentase kemiskinan kabupaten/kota di Provinsi Kalteng.

Apabila dilakukan interpretasi secara matematis, maka setiap kenaikan output sektor pertanian sebesar satu juta rupiah menyebabkan persentase kemiskinan kabupaten/kota akan turun sebesar $1,76 \times 10^{-6}$ persen. Atau kenaikan output sektor pertanian sebesar satu triliun rupiah mampu menurunkan persentase kemiskinan kabupaten/kota di Kalteng sebesar 1,76 persen dengan asumsi variabel lain bersifat tetap atau cateris paribus. Sesuai dengan teori bahwa output sektor pertanian memiliki pengaruh yang negatif dan signifikan terhadap kemiskinan.

Di banyak negara berkembang, hampir seluruh studi memberikan dukungan empiris terkait pandangan sektor pertanian yang telah menjadi pendorong utama pengurangan kemiskinan. Meski hal ini bisa saja terjadi karena beragam alasan termasuk jenis pertanian, tingkat pertumbuhan pertanian, investasi publik dan swasta, serta kebijakan pemerintah itu sendiri [7], namun di sebagian negara Afrika yang mayoritas miskin, intervensi peningkatan produktivitas pertanian mampu mengurangi tingkat kemiskinan secara substansial dan berkelanjutan [15]. Lebih jauh pada wilayah Asia Tenggara, sektor pertanian telah berkontribusi terhadap Produk Domestik Bruto (PDB) yaitu sebesar lebih dari 10 persen dan menyediakan lapangan pekerjaan sebanyak lebih dari sepertiga jumlah penduduknya [5].

Pada sektor perdagangan kenaikan output sebesar satu triliun rupiah mampu menurunkan persentase kemiskinan kabupaten/kota di Kalteng sebesar 1,01x10-6 persen. Atau kenaikan output sektor perdagangan sebesar satu triliun rupiah menyebabkan persentase kemiskinan kabupaten/kota di Kalteng turun sebesar 1,01 persen dengan asumsi variabel lain bersifat tetap. Literatur ekonomi telah menunjukkan bahwa keterbukaan perdagangan adalah kunci pengurangan kemiskinan [19]. Secara umum, perdagangan memengaruhi pendapatan orang miskin melalui berbagai alternatif seperti efek dari pertumbuhan ekonomi, pergerakan harga-harga, stabilitas makro dari pendapatan pemerintah [19]. Pengaruh perdagangan terhadap orang miskin sangat tergantung pada mekanisme spesifik yang dijalankan seperti kompetisi pembuatan barang dan pabrik-pabrik dimana orang miskin sedang bekerja [19].

Kedua variabel baik pertanian maupun perdagangan sangatlah efektif untuk menurunkan angka kemiskinan. Namun demikian, berdasarkan koefisien model regresi yang terbentuk sektor pertanian dianggap memiliki dorongan yang besar dibandingkan sektor perdagangan. Hal tersebut sesuai dengan teori Mellor [12], di mana sektor pertanian yang kuat merupakan syarat utama berhasilnya transformasi struktur ekonomi di negara berkembang seperti Indonesia termasuk Provinsi Kalteng.

Selanjutnya, ditunjukkan efek tetap pada masing-masing kabupaten/kota yang memiliki nilai berbeda-beda antar kabupaten/kota sesuai dengan Tabel 6. Ini menandakan bahwa pada dasarnya masing-masing individu memiliki tingkat kemiskinan yang heterongen atau berbeda- 
beda. Misalnya saja Kabupaten Kotawaringin Barat akan memiliki model kemiskinan sebagai berikut:

$$
T K_{1 t}=8,83+2,39-1,79 \times 10^{-6} A_{1 t}-1,01 \times 10^{-6} G_{1 t}+\mu_{1 t}
$$

dengan $i=1$ atau nomor urut observasi pertama. Jika seluruh variabel dalam persamaan tidak memiliki pengaruh atau cateris paribus maka persentase kemiskinan Kotawaringin Barat nilainya merupakan penjumlahan dari 8,83 dan 2,39 atau 11,22 persen. Pembacaan output serupa juga berlaku untuk kabupaten/kota lainnya dan mengacu pada tabel 6 .

Tabel 6. Efek Tetap Masing-Masing Kabupaten/Kota

\begin{tabular}{|l|c|c|}
\hline \multicolumn{1}{|c|}{ Kabupaten/Kota } & Efek & Intersep \\
\hline Kotawaringin Barat & 2,39697 & 11,23532 \\
\hline Kotawaringin Timur & 5,33401 & 14,17236 \\
\hline Kapuas & 2,18964 & 11,02799 \\
\hline Barito Selatan & $-1,23076$ & 7,60759 \\
\hline Barito Utara & $-1,54943$ & 7,28892 \\
\hline Sukamara & $-2,57976$ & 6,25858 \\
\hline Lamandau & $-2,64929$ & 6,18905 \\
\hline Seruyan & 3,04671 & 11,88505 \\
\hline Katingan & $-0,22528$ & 8,61307 \\
\hline Pulang Pisau & $-1,41383$ & 7,42452 \\
\hline Gunung Mas & $-0,44379$ & 8,39456 \\
\hline Barito Timur & 1,42948 & 10,26782 \\
\hline Murung Raya & $-1,39187$ & 7,44647 \\
\hline Palangka Raya & $-2,91281$ & 5,92554 \\
\hline
\end{tabular}

Seluruh persentase kemiskinan, diwakili oleh nilai intersep yang positif dan bervariasi. Berdasarkan angka ini dapat disimpulkan bahwa Kabupaten Seruyan ada pada peringkat kedua terbesar dalam persentase kemiskinan. Adapun peringkat kedua persentase kemiskinan terkecil terjadi pada Kota Palangka Raya. Hal ini nyaris sesuai dengan publikasi pada periode penelitian dimana Kabupaten Seruyan dan Kota Palangka Raya masing-masing memiliki persentase kemiskinan terparah dan terendah dibandingkan dengan kabupaten lainnya.

\section{$4 \quad$ Kesimpulan}

Berdasarkan hasil analisis dan pembahasan yang telah dijelaskan maka dapat disimpulkan beberapa hal sebagai berikut:

a. Pemodelan regresi data panel dengan fixed effects dan estimasi parameter Seemingly Uncorrelated Regession (SUR) tepat digunakan untuk menganalisis pengaruh sektor pertanian dan perdagangan terhadap persentase kemiskinan Kalteng.

b. Hasil Adjusted R-Square sebesar 0,8592 menunjukkan bahwa variasi output sektor perdagangan dan pertanian mampu menjelaskan variasi tingkat kemiskinan sebesar 85,92 persen dengan mempertimbangkan penambahan variabel lain di dalam model, sedangkan 14,08 persen lain mampu dijelaskan oleh variabel-variabel yang tidak termasuk dalam model.

c. Seluruh variabel berpengaruh negatif dan signifikan terhadap persentase kemiskinan. Setiap kenaikan output sektor pertanian sebesar satu juta rupiah menyebabkan persentase kemiskinan kabupaten/kota akan turun sebesar $1,76 \times 10^{-6}$ persen. Atau kenaikan output sektor pertanian sebesar satu triliun rupiah mampu menurunkan persentase kemiskinan kabupaten/kota di Kalteng sebesar 1,76, sedangkan kenaikan output sektor perdagangan 
sebesar satu triliun rupiah menyebabkan persentase kemiskinan kabupaten/kota di Kalteng akan turun sebesar $1,01 \times 10^{-6}$ persen. Atau kenaikan output sektor perdagangan sebesar satu triliun rupiah mengakibatkan persentase kemiskinan kabupaten/kota di Kalteng turun sebesar 1,01 persen.

Berkaca pada fakta empiris hasil penelitian, maka pengembangan sektor pertanian harus menjadi prioritas dalam pembangunan ekonomi di wilayah Kalteng. Kebijakan yang dilakukan dapat berupa bantuan pupuk bersubsidi melalui kementrian pertanian dan pinjaman modal yang memudahkan petani dengan tingkat bunga rendah. Pada level desa, perlu pemanfaatan Anggaran Dana Desa (ADD) dalam pengembangan produk unggulan di masingmasing wilayah. Hal ini dilakukan demi peningkatan output PDRB pada sektor pertanian. Adapun bagi peneliti selanjutnya dapat mempertimbangkan variabel sektor industri dengan model analisis berupa model panel simultan.

\section{Daftar Pustaka}

[1] Badan Pusat Statistik. Data dan Informasi Kemiskinan Kabupaten/Kota Tahun 2018. 2019. Jakaarta: BPS

[ 2 ] Badan Pusat Statistik Provinsi Kalimantan Tengah. Analisis Sensus Ekonomi 2016 Hasil Listing. Palangka Raya: BPS

[ 3 ] Badan Pusat Statistik Provinsi Kalimantan Tengah. Potret Kemiskinan. 2018. Palangka Raya: BPS

[ 4 ] Baltagi, Badi H. Econometrics. 2011. New York: Springer.

[ 5 ] Fan, Z. and Zhuang, J. (2009). Agricultural Impact of Climate Change: A General Equilibrium Analysis with Special Reference to Southeast Asia, ADBI Working Paper No. 131. Asian Development Bank, Mandaluyong City.

[6] Greene, William H. Econometric Analysis. 2002. New York: Prentice Hall

[ 7 ] Grewal, Bhajan; Grunfeld, Helena and Peter Sheehan. The contribution of agricultural growth to poverty reduction. 2012. Canberra: ACIAR.

[ 8 ] Herawan, Iman. Analisis Eksistensi Sektor Pertanian terhadap Pengurangan Kemiskinan di Pedesaan dan Perkotaan. 2012. Bandung: MIMBAR

[9] https://kalteng.bps.go.id/dynamictable/2017/03/08/194/distribusi-pdrb-provinsi-kaliman tan-tengah-atas-dasar-harga-berlaku-2010-2018-persen-.html.

[10] https://kalteng.bps.go.id/dynamictable/2019/07/29/319/persentase-penduduk-miskin-p0menurut-kabupaten-kota-2013-2018.html.

[11] Imai, Kosuke and Kim, In Song. When Should We Use Unit Fixed Effects Regression Models for Causal Inference with Longitudinal Data? 2019. New York: American Journal of Political Science.

[12] Mellor, John D., Agricultural Development and Economic Transformation Promoting Growth With Poverty Reduction. 2017. Washington DC: Palgrave Macmillan.

[13] Mitra, Devashish. Trade Liberalitation and Poverty Reduction. 2016. New York: IZA World of Labour.

[14] Mućk, Jakub. Econometrics of Panel Data. 2019. Polandia: Szkoła Główna Handlowa.

[15] Mwabu, Germano. Agriculture Productivity And Poverty Eradication In Africa. 2016. Kenya: University of Nairobi.

[16] Raihanah, Astari. Pengaruh Return On Assets, Earnings Per Share, Ekuitas Perusahaan, Dan Pengungkapan CSR Terhadap Risiko Sistematik Emiten Sri-Kehati Periode 20122015. 2016. Jakarta: Sekolah Tinggi Ilmu Statistik.

[17] Stefan, Camelia. Human Capital As A Determinant Of The Economic Growth - A Panel Data Approach. 2016. United Kingdom: International Journal Of Economics, Commerce 
And Management.

[18] Wooldridge, Jeffrey M. Econometric Analysis of Cross Section and Panel Data. 2002. Cambridge: MIT Press.

[19] World Trade Organization. Trade And Poverty Reduction New Evidence Of Impacts In Developing Countries. 2018. United Nations: World Bank Group 